American Journal of Animal and Veterinary Sciences 2 (1): 1-5, 2007

ISSN 1557-4555

(C) 2007 Science Publications

\title{
Effects of Steam Conditioning and Extrusion Temperature on Some Anti-nutritional Factors of Soyabean (Glycine max) for Pet Food Applications
}

\author{
${ }^{1}$ Purushotham, B., ${ }^{1}$ Radhakrishna, P.M. and ${ }^{2}$ Sherigara, B.S. \\ ${ }^{1}$ Research and Development Centre, Tetragon Chemie Pvt. Ltd., Bangalore \\ ${ }^{2}$ Department of Post Graduate Studies and Research in Industrial Chemistry, Kuvempu University \\ Shankaraghatta, Shimoga-577 451
}

\begin{abstract}
Extrusion processing of vegetable ingredients such as soyabean (Glycine max) characteristically depends on associating process conditions that influence the product qualities. The process parameters were optimized for extrusion of steam-conditioned material in order to obtain the maximum nutritive value by inactivating the anti-nutritional factors such as urease, trypsin inhibitors and lipase. The processing conditions such as moisture content, temperature and time were precisely controlled to avoid over heating or under heating which otherwise would result in a product of lower nutritional quality. The urease activity and Trypsin inhibitors were measured in steam conditioned extruded soyabean material and test results indicated that urease activity units and trypsin inhibitory units were reduced from 2.0 and 50 to 0.3 and 5 respectively in extruded soyabean during the extrusion process. These results were used for comparative evaluation of 'inactivation levels of anti-nutritional factors' for optimizing the processing conditions of the steam conditioner and extruder for producing soyabean products for pet food applications. Stability studies were done on pet food samples and free fatty acid content and peroxide values were used as the criteria to evaluate the lipase activity in extruded soyabean samples. Extrusion of steam-conditioned soyabean material inactivated the antinutritional factors making extruded soyabean an ideal ingredient for pet food and its stability.
\end{abstract}

Key words: Inactivation, urease, trypsin inhibitors, lipase, pet food and stability

\section{INTRODUCTION}

Nutrition plays a complex and controversial role in Animal Health. Today, the animal feed industry worldwide is becoming increasingly dependent upon vegetable protein sources. As the major vegetable protein commodity, soyabean and its products are becoming more important as dietary raw materials for both humans and animals. Most of the soybean, i.e., $97 \%$ being used in animal feed with $46 \%$ going to poultry, $32 \%$ to swine and $18-19 \%$ to dairy and beef cattle feed $^{[1]}$. The major producers in the world, U.S., Argentina, Brazil and China, account for $87 \%$ of the total production

Difficulties were encountered initially $60-80$ years ago, for the use of Soya bean products in Pet Food. This was mostly related to the lack of sufficient scientific information on nutrient quality of processed Soya beans, which was indicated to be appropriate for animals and its well being ${ }^{[2,3]}$. Unprocessed soybeans contain Trypsin inhibitors, Urease, Lipase, Lectins, Saponins, Phytoestrogens, Oligossacharides and
Allergenic proteins such as glycinin and conglycinin. The levels and effect of these anti-nutritional factors in different soy products have been discussed by Russett and Liener ${ }^{[4,5]}$. The anti-nutritional parameters from raw soyabean have been well documented to cause gastrointestinal disturbances, intestinal damage, increased disease susceptibility and reduced performances by Barratt et $\mathrm{al}^{[6]}$. Another study highlighted that extrusion destructs the Trypsin Inhibitors present in soyabeans ${ }^{[7]}$. As these antinutritive factors are heat labile, the adequate steam and extrusion conditioning studies were undertaken to understand the optimal steam conditioning and extrusion operations to make the extruded soyabean an useful nutritional ingredient for pet food applications.

The present study was undertaken with the following objectives:

* To optimize the steam conditioning and extrusion operations for inactivation of anti-nutritional factors in soyabean.

* To produce a nutritive ingredient of soyabean by inactivation of anti-nutritional factors

Corresponding Author: $\quad$ Purushotham, B., Research and Development Centre, Tetragon Chemie Pvt. Ltd., Yelahanka New Town, Bangalore-64 , India Tel: 918028460060 
* To study the stability of 'Pet food with extruded soyabean' and 'Petfood with raw soyabean'

\section{MATERIALS AND METHODS}

Steam conditioning: The pre-extrusion processing of the raw material involved 3 main steps: grinding, blending and moisturizing with steam in the conditioner. The raw soyabeans were ground through 4 $\mathrm{mm}$ screen and steam conditioned in the twin-screw conditioner by injecting steam at $2 \mathrm{~kg} \mathrm{~cm}^{-2}$ pressure. During preconditioning, the raw granular soyabean powder was uniformly blended, moistened with live steam. The moisture and temperature of the soyabean powder were maintained at $14-18 \%$ and $60-70^{\circ} \mathrm{C}$ respectively through out the conditioning process.

Extrusion: Conditioned soyabean material was extruded as described by Lin et al. ${ }^{[8]}$ in Instapro Extruder Model $2000 \mathrm{R}$ between $40-140^{\circ} \mathrm{C}$ and total fourteen extruded samples were collected at various increments of temperature in order to study the level of antinutritional factors. Eight samples were collected at $10{ }^{\circ} \mathrm{C}$ increments of temperature from 40 to $110{ }^{\circ} \mathrm{C}$ and six samples were collected at $5^{\circ} \mathrm{C}$ increments of temperature from $110^{\circ} \mathrm{C}$ to $140^{\circ} \mathrm{C}$. The urease was measured as N.g. min $^{-1}$ for urease activity index as discussed in Soyabean products ${ }^{[9]}$ and trypsin inhibitors were measured as mg Trypsin Units Inhibited (TUI) as discussed by Kakade et al. ${ }^{[10]}$, in extruded Soyabean samples. Two Pet food samples, test $\mathrm{E}$ and $\mathrm{R}$ which were formulated with wheat, rice, corn gluten meal and soyabean was extruded as pellets as explained by Rokey et al. ${ }^{[11]}$ and Johnston ${ }^{[12]}$. Test E was contained $15 \%$ extruded soyabean and test $\mathrm{R}$ contained $15 \%$ raw soyabean.

Stability tests: Extruded pellets of Pet food of test E and $\mathrm{R}$ were subjected to product stability studies as described by Kenneth ${ }^{[13]}$. Stability studies were planned for determining the product stability at atmospheric and accelerated conditions. The atmospheric conditions were varied from 24 to $38^{\circ} \mathrm{C}$ and accelerated conditions were kept maintained at $40 \pm 1{ }^{\circ} \mathrm{C}$ temperature and $60 \%$ $\pm 1 \%$ RH. Samples were kept for 95 days at accelerated conditions and 365 days at atmospheric conditions. Stability test was carried out on pre-extrusion samples, samples kept at accelerated conditions and on the samples kept at atmospheric conditions for 365 days. Total Free fatty acid content and Peroxide value was estimated in pet food samples containing soyabean and used as the criteria to find out the activity of lipase in extruded soyabean samples for determining the stability of the pet foods. Proximate analysis ${ }^{[14]}$ was carried out to find out the changes during extrusion in some of the major nutrients present in the extruded pet food samples kept at accelerated and atmospheric conditions

\section{RESULTS AND DISCUSSION}

Anti-nutritional factors: A Test value for the Urease activity in various extruded samples was evaluated and data from the Table 1 indicated that urease activity was decreased with increase in the extrusion temperature. Urease activity in raw soyabeans reduced from 2 to 0.046 during extrusion and this reduction was somewhat rapid up to $100^{\circ} \mathrm{C}$ of temperature where the values were reduced to 0.5 and later on to 0.046 with steady reduction indicating that urease enzyme is sensitive to extrusion temperature. . From the data, it was clear that the urease activity was inactivated to < 0.3 between $1100-1400^{\circ} \mathrm{C}$ extrusion temperatures and these results co-relate well with the values as indicated by Swiss regulations ${ }^{[15]}$.

\begin{tabular}{lcl} 
Table 1: & \multicolumn{2}{c}{ Effect of temperature on urease activity } \\
\hline Sample & $\begin{array}{c}\text { Extrusion temperature } \\
{ }^{\circ} \mathrm{C}\end{array}$ & $\begin{array}{l}\text { Urease activity index } \\
(\mathrm{pH} \text { rise }) 2^{*}\end{array}$ \\
No. & 40 & 1.55 \\
\hline 1. & 50 & 1.5 \\
2. & 60 & 1.3 \\
3. & 70 & 1.1 \\
4. & 80 & 1.1 \\
5. & 90 & 0.7 \\
6. & 100 & 0.5 \\
7. & 110 & 0.258 \\
8. & 115 & 0.156 \\
9. & 120 & 0.118 \\
10. & 125 & 0.101 \\
11. & 130 & 0.083 \\
12. & 135 & 0.048 \\
13. & 140 & 0.046 \\
14. &
\end{tabular}

The Trypsin inhibitor activity units were also decreased with increase in extrusion temperature. From the data presented in Table 2, it was indicated that the Trypsin Inhibitor activity units in raw soyabeans were reduced from 51 to $<2 \mathrm{TUI}^{[14]}$ between $40-140^{\circ} \mathrm{C}$ extrusion temperatures. Though initial values at $40-$ $80^{\circ} \mathrm{C}$ indicated slow inactivation of Trypsin Inhibitor activity units from 51 to 34 TUI, the inactivation is increased with further rise in extrusion temperature from 80 to $140^{\circ} \mathrm{C}$. This phenomenon of inactivation of urease and trypsin inhibitors points out the information that urease enzyme is much sensitive to extrusion temperature when compared to Trypsin inhibitors. 
Table 2: Effect of temperature on trypsin inhibitory activity

\begin{tabular}{lcc}
\hline Sample No. & $\begin{array}{l}\text { Extrusion temperature } \\
{ }^{\circ} \mathrm{C}\end{array}$ & $\begin{array}{c}\text { Trypsin Inhibitory } \\
\text { units } \mathrm{mg} / \mathrm{g}\end{array}$ \\
\hline 1. & $\mathbf{4 0}$ & $51^{*}$ \\
2. & 50 & 50 \\
3. & 60 & 45 \\
4. & 70 & 41 \\
5. & 80 & 34 \\
6. & 90 & 21 \\
7. & 100 & 14 \\
8. & 110 & 9 \\
9. & 120 & 5 \\
10. & 125 & $<2$ \\
11. & 130 & $<2$ \\
12. & 135 & $<2$ \\
13. & 140 & $<2$ \\
\hline
\end{tabular}

*for raw Soya beans

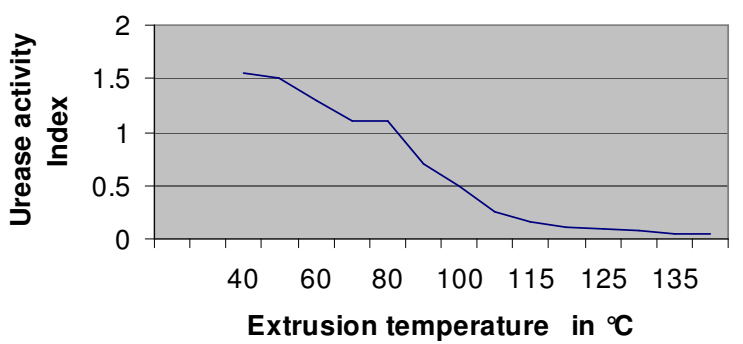

Fig. 1: Effect of extrusion temperature on urease activity

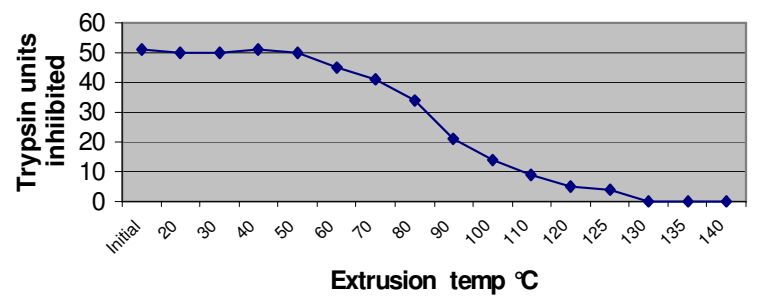

Fig. 2: Effect of extrusion temperature on typsin inhibitory activity

It can be summarized from the data that antinutritinal factors Urease and Trypsin Inhibitors were inactivated to desired levels ${ }^{[15]}$ during extrusion at temperatures between 120 and $140^{\circ} \mathrm{C}$ making extruded soyabean a stable and suitable ingredient for pet food formulations.

Product stability studies: From the Stability studies data for test $\mathrm{E}$ and $\mathrm{R}$ samples, it is indicated from the Table 3 at over a period of time, the increase in peroxide values were considerably reduced for test $\mathrm{E}$ samples compared to test $\mathrm{R}$ samples. The peroxide results for test $\mathrm{E}$ samples kept at accelerated and atmospheric conditions indicated that the values were increased from 0.9 and $1.1 \mathrm{meq} \mathrm{kg}^{-1}$ to 3.96 to $4.9 \mathrm{meq}$ $\mathrm{kg}^{-1}$ respectively propounding almost to 4.4 times increase in peroxide levels. The results for test $\mathrm{R}$ samples kept at accelerated and atmospheric conditions indicated that the peroxide levels were increased from 1.1 and 0.8 meq $\mathrm{kg}^{-1}$ to 35.25 to $37.50 \mathrm{meq} \mathrm{kg}^{-1}$ respectively resulting almost to 40 times increase in peroxide value. The peroxide values of test $E$ and $R$ indicated that there is 10 times increase in the peroxide levels for test $\mathrm{R}$ samples compared to test $\mathrm{E}$ samples emphasizing the advantages of extrusion of soyabean for pet food formulations.

The free fatty acid content which was calculated as oleic acid showed that for test E samples which were kept at accelerated and atmospheric conditions, the free fatty acid content was increased from 0.42 and $0.49 \%$ to 1.7 to $1.91 \%$ respectively resulting almost to 4 times increase in free fatty acid content. Where as for the test $\mathrm{R}$ samples which were kept at accelerated and atmospheric conditions, the free fatty acid content increased from 0.69 and $0.72 \%$ to 6.10 to $6.90 \%$ respectively leading almost to 9 times increase in free fatty acid content. Results also indicated that increase in free fatty acid content for sample $\mathrm{E}$ is reduced by 5 times when compared to test $\mathrm{R}$ samples.

Test sample $\mathrm{E}$ was stable for 365 days at atmospheric conditions and 90 days at accelerated conditions indicating relatively less oxidation of pet food samples produced using extruded soyabean in the formulations. These observations are supported by the data as per the Table 3 where the peroxide levels in test $\mathrm{R}$ for $60^{\text {th }}$ day samples kept at atmospheric conditions are $4.1 \mathrm{meq} \mathrm{kg}^{-1}$ which are comparatively equal to 365 days test $E$ samples with the peroxide values of 4.9 meq $\mathrm{kg}^{-1}$ of pet food. It was also noticed that peroxide values are further increased after 90 days indicating the instability of test $\mathrm{R}$ sample due to presence of lipase in raw Soya beans. This instability was not observed in test E samples where extruded soyabean was included in the pet food formulations. The marginal increase in free fatty acid and peroxide values may be attributed to auto oxidation. This consistency in stability may be due to inactivation of lipase during extrusion of steamconditioned material and hence contributing to low free fatty acid content and decrease in peroxide value when extruded soyabean is incorporated in pet food formulations. The sudden increase of peroxide and free fatty acid values clearly indicated that lipase is active in raw soyabean contributing to the production of free fatty acids, which further resulted in increase in peroxide value due to oxidation. With these examinations, usage of raw soyabeans in pet food formulations is not ideal to visualize as the quality ingredient emphasizing the importance of steam conditioning and extrusion of soyabeans for the inactivation of antinutritional factors for pet food applications and stability. 
American J. Animal \& Vety. Sci., 2 (1): 1-5, 2007

Table 3: Peroxide values in extruded pet food at different atmospheric conditions

\begin{tabular}{|c|c|c|c|c|c|c|c|c|}
\hline \multirow[t]{3}{*}{ No. of Days } & \multicolumn{4}{|c|}{ Peroxide value meq $/ \mathrm{kg}$ of the pet food } & \multicolumn{4}{|c|}{ FFA as oleic acid $\%$} \\
\hline & \multicolumn{2}{|c|}{ At accelerated conditions } & \multicolumn{2}{|c|}{ At atmospheric conditions } & \multicolumn{2}{|c|}{ At accelerated conditions } & \multicolumn{2}{|c|}{ At atmospheric conditions } \\
\hline & Test E & Test $\mathrm{R}$ & Test E & Test $\mathrm{R}$ & Test E & Test $\mathrm{R}$ & Test E & Test $\mathrm{R}$ \\
\hline 1 & 0.90 & 1.01 & 1.10 & 0.80 & 0.42 & 0.69 & 0.49 & 0.72 \\
\hline 15 & 1.10 & 12.18 & 1.05 & 2.50 & 0.51 & 1.21 & 0.51 & 0.69 \\
\hline 30 & 1.20 & 15.60 & 1.41 & 3.00 & 0.68 & 1.80 & 0.50 & 0.69 \\
\hline 45 & 1.38 & 16.19 & 1.50 & 3.50 & 0.87 & 2.10 & 0.67 & 0.90 \\
\hline 60 & 2.60 & 18.32 & 1.90 & 4.10 & 0.99 & 3.19 & 0.68 & 1.01 \\
\hline 75 & 2.79 & 29.10 & 2.10 & 14.00 & 1.26 & 4.10 & 0.75 & 1.90 \\
\hline 90 & 3.96 & 35.25 & 2.60 & 16.09 & 1.70 & 6.10 & 0.91 & 2.00 \\
\hline 120 & & & 2.91 & 17.20 & & & 1.21 & 2.10 \\
\hline 240 & & & 3.85 & 22.40 & & & 1.51 & 4.20 \\
\hline 365 & & & 4.90 & 37.50 & & & 1.91 & 6.90 \\
\hline
\end{tabular}

Table 4: Proximate analysis of Pet food with extruded soyabean (Test E) during stability studies

\begin{tabular}{|c|c|c|c|c|c|}
\hline \multirow[t]{2}{*}{ Parameter } & \multirow[t]{2}{*}{ Initial Values } & \multicolumn{2}{|c|}{ Accelerated conditions } & \multicolumn{2}{|c|}{ Atmospheric conditions } \\
\hline & & $60^{\text {th }}$ day & $90^{\text {th }}$ day & $120^{\text {th }}$ day & $365^{\text {th }}$ day \\
\hline Crude protein \% & 24.99 & 24.55 & 25.01 & 24.61 & $25.12 \pm 0.44$ \\
\hline Crude fat $\%$ & 11.10 & 10.90 & 10.70 & 11.30 & $10.61 \pm 0.59$ \\
\hline Crude fibre $\%$ & 02.90 & 02.99 & 3.20 & 02.89 & $03.10 \pm 0.30$ \\
\hline Calcium \% & 01.65 & 01.69 & 1.60 & 01.65 & $01.70 \pm 0.30$ \\
\hline Phosphorous \% & 01.10 & 01.05 & 1.20 & 01.13 & $01.12 \pm 0.10$ \\
\hline
\end{tabular}

Further more as indicated in Table 4, proximate analysis values for the test $\mathrm{E}$ pet food samples specifies that extrusion of soyabean between 120 and $140^{\circ} \mathrm{C}$ temperatures does not hamper the important major chemical nutrients, but improves the nutritional value of soyabean by inactivation of antinutritional factors. These data on pet product stability, unchanged chemical nutrients after steam conditioning and extrusion indicates that extruded soyabean is a viable ingredient for pet food formulations. In fact extruded soyabean is an economical nutrient source for protein and fat in animal diet formulations, compared to Soya protein hydrolysate i.e, concentrate, which is an expensive ingredient.

\section{ACKNOWLEDGMENTS}

We sincerely thank Research \& Development center, Tetragon Chemie Pvt. Ltd., Bangalore and Department of Post graduate studies and Research in industrial chemistry, Kuvempu University, Shimoga for their support.

\section{REFERENCES}

1. Environment Directorate, Paris, 2001. Consensus Document on Compositional Considerations for New Varieties of Soybean: Key Food and Feed Nutrients and Antinutrients.
2. Hill, R.C., 1995. Soya in pet foods: Fact or fiction? From proceedings of Pet food Forum, pp: 72-80, Watt Publishing Co., Mt. Morris, Illinois, USA.

3. Hill, R.C. et al., 2000. The effect of texturized vegetable protein containing soy concentrate on oroileal transit of chromic oxide in cannulated dogs. J. Ani. Sci., 78: 2633-2638.

4. Russett, J.C., 1998. Soy protein concentrate in animal feeds. Ani. Nutr. Res. Notes. SPC-T-47, pp: $1-15$.

5. Liener, I.E., 1994. Implication of anti-nutritional components in soybean foods. Crit. Rev. Food Sci. \& Nutr., 34: 31-67.

6. Barratt, M.E.J., P.J. Strachan and P. Porter, 1978. Antibody mechanisms implicated in digestive disturbances following ingestion of soya protein in calves and piglets. Clin. Exp. Immunol., 31: 305.

7. Clarke. E. and J. Wiseman, 1999. Extrusion impairs trypsin inhibitor activity in Soya bean meal. Feed Tech., 3: 29-31.

8. Lin, S.H. and H.E. Huff, 1997. Effects of lipids and processing conditions on degree of starch gelatinization of extruded dry pet food. LebemsmWiss. U.-Technol., 30: 754-761.

9. Soyabean Products, ISO 5506, 1998. Determination of Urease Activity. Robert C. Miller, Extrusion Cooking of Pet Foods, Cereal Food World, 30: 323-327. 
10. Kakade, S. and Liener, 1969. Bio. Chem. J., Vol. 40.

11. Rokey, G.J., Wenger Manufacturing, Inc, Sabetha, Kansas, USA. Feed Tech., Vol. 3, Nr. 4, Producing pet food by extrusion cooking.

12. Johnston, G.L., 1978. Technical and practical processing conditions with single screw cooking extruders: Cooking Extruding Techniques, ZDS, Solingen-Grafeath, Germany.
13. Kenneth, A.C., G.L. Amidon and V.J. Stella, 1985. Chemical Stability of Pharmaceuticals. II Edn.

14. Official Methods of Analysis of AOAC International. 17th Edn., Rev. 1.

15. Swiss Regulations, Ordinance on the Feedstuffs Manual, Annex 1, SR 916.307.1. 